\title{
LABORATORY STUDIES ON THE VARICELLA-ZOSTER VIRUS
}

\author{
E. VAlerie Meurisse \\ Virus Reference Laboratory, Central Public Health Laboratory, \\ Colindale Avenue, London
}

\section{Plate XXV}

Although isolation of virus from cases of varicella and zoster in cell cultures was first reported by Weller and Stoddard (1952) and serial cultivation of the virus from varicella by Weller (1953), there are still difficulties in transmitting and storing these viruses in the laboratory. Both viruses produce an identical well-defined cytopathic effect in a variety of cell cultures and appear to show an affinity for primary human tissues such as human foreskin and human embryo skin muscle (Weller), human amnion (Taylor-Robinson, 1959) and human thyroid (Caunt, 1963). Several workers (Weller, Witton and Bell, 1958; Taylor-Robinson; Váczy et al., 1962; Gold, 1965) have shown that these viruses can be passaged only when suspensions of infected cells are used as the inoculum. The reason for this limitation is that few infectious virus particles are present extracellularly.

This paper reports a study of the growth and survival of these viruses, of the cells suitable for their cultivation and of their isolation from clinical materials.

\section{MATERIALS AND METHODS \\ Cell cultures}

Human amnion. Primary cultures were prepared by a technique based on that of Lane and Marshall (1957). The growth medium was Earle's balanced salt solution to which was added, per $100 \mathrm{ml}$, lactalbumin hydrolysate $0.25 \mathrm{~g}$, horse serum $15 \mathrm{ml}$, human serum $5 \mathrm{ml}$, and sodium bicarbonate $0.05 \mathrm{~g}$. Maintenance medium was Morgan, Morton and Parker's medium 199 plus 2 per cent. horse serum and 0.22 per cent. sodium bicarbonate.

Human thyroid. Primary cultures were prepared by the method of Pulvertaft et al. (1959). The growth medium was medium 199 with 5 per cent. calf serum and 0.09 per cent. sodium bicarbonate. Maintenance medium was medium 199, 2 per cent. calf serum and 0.18 per cent. sodium bicarbonate.

Human embryo lung. A cell strain was established as described by Hayflick and Moorhead (1961). Growth medium was Eagle's basal medium with 10 per cent. calf serum and 0.07 per cent. sodium bicarbonate, and maintenance medium was this basal medium with 2 per cent. calf serum and $0 \cdot 11$ per cent. sodium bicarbonate.

HeLa cells were grown, as described by Pereira and Kelly (1957), in Gey's solution with 0.5 per cent. lactalbumin hydrolysate and 5 per cent. rabbit serum. Maintenance medium was Gey's solution with 0.25 per cent. lactalbumin hydrolysate and without serum.

Monkey kidney. Primary kidney cultures from both rhesus and vervet monkeys were prepared by a method based on that described by Rappaport (1956). The growth medium

Received 7 Aug. 1968; accepted 20 Jan. 1969.

J. MED. MICROBIOL.-VOL. 2 (1969) 
consisted of Hanks' balanced salt solution with the addition of 0.5 per cent. lactalbumin hydrolysate, 2 per cent. bovine serum and 0.05 per cent. sodium bicarbonate. Maintenance medium was medium 199 plus 2 per cent. calf serum and $\mathbf{0 . 2 2}$ per cent. sodium bicarbonate.

$V 3 A$ cells. The Glaxo continuous line of vervet monkey kidney cells was grown in medium 199 with 5 per cent. calf serum and 0.18 per cent. sodium bicarbonate and maintained in medium 199, 2 per cent. calf serum and 0.22 per cent. sodium bicarbonate.

RK13 cells. The Glaxo continuous line of rabbit kidney cells was grown in medium 199 with 5 per cent. calf serum and 0.09 per cent. sodium bicarbonate, and was maintained in medium 199 with 2 per cent. calf serum and $0 \cdot 18$ per cent. sodium bicarbonate.

Antibiotics. All growth and maintenance media contained 200 units penicillin and $200 \mu \mathrm{g}$ streptomycin per $\mathrm{ml}$.

\section{Sources of viruses}

Specimens from patients. (1) Vesicle fluid. Specimens were obtained from 23 patients with chickenpox and three patients with zoster. It was collected with very fine glass pipettes and, irrespective of the original quantity, immediately diluted in $1 \mathrm{ml}$ of medium 199 . (2) Urine. About $25 \mathrm{ml}$ of a freshly voided midstream specimen of urine was collected from each of 23 patients with chickenpox and from one patient with zoster, on the same day as the vesicle fluid.

Specimens from necropsy material. (1) Fluid from skin lesions was obtained from a fatal case of chickenpox and a fatal case of zoster. It was treated in the same way as vesicle fluid from patients. (2) Fluid was aspirated from the heart of a fatal case of chickenpox. (3) Liver and lung. Both these tissues were obtained from a fatal case of zoster and lung tissue was also obtained from a fatal case of chickenpox. (4) Ganglia of the fifth cranial nerve were obtained from 66 persons who had died in hospital from a variety of natural causes.

Stock strains of viruses. Six strains of varicella virus isolated from vesicle fluid from six patients with chickenpox were used. The strains were denoted "Marsden ", "129", " 1697 ", " 121 ", " 730 " and " 8 ". Two strains of herpes zoster virus consisted of one strain of zoster, " $R$ ", similarly isolated from vesicle fluid and another strain of zoster, "Pittaway", isolated from both vesicle-skin scrapings and lung tissue extract from a fatal case.

\section{Methods of isolation}

(1) The diluted vesicle fluid was inoculated directly into three or four cell cultures, each tube receiving $0.25-0.30 \mathrm{ml}$ of inoculum. (2) Urine. As described by Stern, Lambert and Shakespeare (1963), each specimen was centrifuged within $6 \mathrm{hr}$ of collection. The cell deposit was inoculated in $0.5-\mathrm{ml}$ volumes into each of two human amnion cultures and two thyroid cell cultures, and the supernatant fluid was inoculated in 1-ml volumes into further cultures of these two kinds. (3) Liver and lung. Specimens of these tissues were homogenised and prepared as 20 per cent. suspensions in medium 199. They were inoculated into either two human amnion and two human thyroid cultures, or three human amnion cultures, each tube receiving $0.25 \mathrm{ml}$ of suspension. (4) Ganglia. These either were processed by mincing or trypsinisation directly upon receipt or were stored at $-65^{\circ} \mathrm{C}$ until cell cultures became available. At least $1 \mathrm{ml}$ of extract from each specimen was tested; it was subdivided between three tubes of human amnion cultures.

All inoculated tubes were incubated at $37^{\circ} \mathrm{C}$. The human amnion tubes were held stationary for the first $24 \mathrm{hr}$ and then rolled; the thyroid tubes were held stationary throughout the incubation period. All tubes received fresh maintenance medium after $24 \mathrm{hr}$.

Examination of cultures. The cultures were examined microscopically for the characteristic cytopathic effect (CPE) over a period of 21 days. If no cytopathic effect was observed the cultures were discarded as negative.

Passage of virus. This was done by transfer of infected cells detached mechanically or by trypsinisation from the infected cultures. 
Examinations for extracellular virus. The Marsden strain of chickenpox virus and the Pittaway strain of zoster virus were studied in different cell cultures and tested for the presence of cell-free virus. Cultures of human amnion, human thyroid, human embryo lung, HeLa cells, rhesus monkey kidney and V3A cells grown in $4 \mathrm{oz} .(120 \mathrm{ml})$ bottles were inoculated with infected cells containing one or other of these two viruses. The infected cultures were incubated for several days at $37^{\circ} \mathrm{C}$ and in those selected for the experiments more than half the cell sheet showed the characteristic cytopathic changes. Three methods of obtaining cell-free virus were attempted.

(1) The fluid medium from each bottle was removed and centrifuged at $800 \mathrm{~g}$ for $10 \mathrm{~min}$. in a refrigerated centrifuge to deposit any cells. The supernatant fluid was then inoculated in $1-\mathrm{ml}$ amounts into each of five or six tubes of fresh cell cultures of the same type as those providing the harvests. These tubes were incubated at $37^{\circ} \mathrm{C}$. The maintenance medium in them was replaced after $24 \mathrm{hr}$.

(2) The infected cell sheet of the bottle used for method (1) was covered with $0 \cdot 2$ per cent. trypsin solution and incubated at $37^{\circ} \mathrm{C}$ for $10 \mathrm{~min}$. The suspension of detached cells was centrifuged at $28 \mathrm{~g}$ for $10 \mathrm{~min}$, and the deposit then resuspended in $1.4 \mathrm{ml}$ medium 199 . This suspension was treated in a 60 watt MSE ultrasonic disintegrator for $45 \mathrm{~s}$ with a $\frac{3}{8}$ in. $(9 \mathrm{~mm})$ probe, the tube being cooled with crushed ice. It was then centrifuged at $800 \mathrm{~g}$ for $10 \mathrm{~min}$. The supernate was inoculated in $0.1-\mathrm{ml}$ volumes into two tubes of the same type of cell culture as used to prepare the inoculum.

(3) The infected cell sheet was covered with $10 \mathrm{ml}$ fresh medium 199 , quickly frozen in a mixture of solid $\mathrm{CO}_{2}$ and methyl alcohol, and immediately thawed in a waterbath at $37^{\circ} \mathrm{C}$. This cycle was repeated six times. The cell debris was deposited by centrifugation. The supernate was inoculated in $0 \cdot 1-\mathrm{ml}$ volumes into two cell culture tubes as before.

\section{Storage of virus}

Three methods of storage were attempted and the survival of virus studied. Monolayers of human amnion cells infected with varicella or zoster virus were grown in medical flat 2-oz. or 4-oz. (60- or $120-\mathrm{ml})$ bottles. Those selected for the experiment showed cytopathic changes affecting $30-50$ per cent. of the cells.

(1) The maintenance medium from each bottle was discarded. Sufficient medium 199 containing 10 per cent. horse serum to cover the cell sheet was added and the bottles were frozen in a cabinet at $-65^{\circ} \mathrm{C}$ in a flat position. After $6 \mathrm{mth}$, bottles were thawed rapidly in a $37^{\circ} \mathrm{C}$ waterbath, the cells were scraped off with a pasteur pipette and the suspension was distributed in $0.2-\mathrm{ml}$ volumes into two amnion and two thyroid cell cultures.

(2) Human amnion or thyroid cell sheets infected with varicella or zoster virus were trypsinised and the cells after centrifugation were resuspended as a ten-fold concentrate in medium 199 containing 10 per cent. serum; horse serum was used for cultures of amnion cells and calf serum for cultures of thyroid cells. Dimethyl sulphoxide (DMSO) or glycerol as preserving agents were added so that the final concentration of either was 10 per cent. Suspensions of cells from a $20-\mathrm{oz}$. bottle were distributed in $1-\mathrm{ml}$ volumes into four ampoules, frozen by reduction of temperature at the rate of $1^{\circ} \mathrm{C}$ per min. until $-40^{\circ} \mathrm{C}$ was reached (Nagington and Greaves, 1962) and then stored either at $-65^{\circ} \mathrm{C}$ or in liquid nitrogen at $-184^{\circ} \mathrm{C}$. After a minimum of 3 days' storage, ampoules were thawed at intervals and the cells from them inoculated into human amnion or thyroid cultures.

(3) Infected lung suspension (Pittaway virus) was stored at $-65^{\circ} \mathrm{C}$ without the addition of dimethyl sulphoxide or glycerol for $4 \mathrm{yr}$.

\section{RESULTS}

\section{Isolation of viruses from clinical specimens}

Twenty-six samples of vesicle fluid and 23 specimens of urine were collected from 26 hospital patients with either chickenpox or zoster. From the vesicle 
fluids, 16 varicella-zoster viruses were isolated, 15 from patients with varicella and one from a patient with zoster (table I). No viruses were isolated from the urine specimens.

\section{TABLE I}

Isolation of virus from vesicle fluid from patients with chickenpox or zoster indicated by the production of a cytopathic effect (CPE) in human amnion and human thyroid cultures

\begin{tabular}{|c|c|c|c|c|}
\hline \multirow{2}{*}{ Disease } & \multirow{2}{*}{$\begin{array}{l}\text { Specimen of vesicle } \\
\text { fluid no. }\end{array}$} & \multirow{2}{*}{$\begin{array}{l}\text { Day after onset of } \\
\text { illness when vesicle } \\
\text { fluid was collected }\end{array}$} & \multicolumn{2}{|c|}{$\begin{array}{l}\text { Production of CPE (and day } \\
\text { of culture CPE first seen) in }\end{array}$} \\
\hline & & & $\begin{array}{l}\text { amnion } \\
\text { culture }\end{array}$ & $\begin{array}{l}\text { thyroid } \\
\text { culture }\end{array}$ \\
\hline \multirow[t]{4}{*}{ Chickenpox . } & $\begin{array}{l}1 \\
2 \\
3 \\
4 \\
5 \\
6\end{array}$ & $\begin{array}{l}5 \\
3 \\
5 \\
2 \\
3 \\
1\end{array}$ & $\begin{array}{l}\cdots \\
- \\
\overline{-} \\
\overline{+}(6)\end{array}$ & $\begin{array}{l}\bar{t}^{*}(7) \\
\overline{-} \\
\overline{+}(3)\end{array}$ \\
\hline & $\begin{array}{r}7 \\
8 \\
9 \\
10 \\
11 \\
12\end{array}$ & $\begin{array}{l}2 \\
2 \\
3 \\
2 \\
2 \\
2\end{array}$ & $\begin{array}{l}+(4) \\
+(4) \\
= \\
= \\
+(5)\end{array}$ & $\begin{array}{l}+(4) \\
+(4) \\
-1 \\
+(9) \\
+(5)\end{array}$ \\
\hline & $\begin{array}{l}13 \\
14 \\
15 \\
16 \\
17 \\
18\end{array}$ & $\begin{array}{l}4 \\
2 \\
4 \\
5 \\
1 \\
3\end{array}$ & $\begin{array}{l}\overline{+}(3) \\
+(10) \\
+(10) \\
+\end{array}$ & $\begin{array}{l}+(5) \\
+(2) \\
+(1) \\
+(14) \\
+(1) \\
+(11)\end{array}$ \\
\hline & $\begin{array}{l}19 \\
20 \\
21 \\
22 \\
23\end{array}$ & $\begin{array}{l}3 \\
2 \\
4 \\
2 \\
2\end{array}$ & $\begin{array}{l}\overline{+}(13) \\
\overline{+} \\
\overline{+}(15)\end{array}$ & $\begin{array}{l}- \\
\overline{+}(5) \\
+(6) \\
+(6)\end{array}$ \\
\hline Zoster. & $\begin{array}{l}24 \\
25 \\
26\end{array}$ & $\begin{array}{l}6 \\
7 \\
9\end{array}$ & $\begin{array}{l} \pm(12) \\
-\end{array}$ & $\begin{array}{l} \pm(4) \\
\pm\end{array}$ \\
\hline
\end{tabular}

* Tubes were discarded at 21 days if no cytopathic effect was observed; thyroid culture of specimen 9 was discarded at 18 days.

$\ldots==$ Not tested.

Varicella-zoster viruses were identified by their characteristic cytopathic effect in both human thyroid and human amnion cultures. This identity was confirmed in two patients with chickenpox, from whom virus had been isolated, by the demonstration of a four-fold rise in the titre of complement-fixing antibody. When a virus multiplied in both types of cell it was often detected several days earlier in the thyroid cultures. From seven specimens (no. 2, 10, 13, 16, 18,21 and 22) virus was isolated in thyroid cultures only, and from one specimen (no. 20) it was isolated in human amnion cells only. The sensitivity of the two 
types of cell to varicella-zoster viruses suggests that these viruses were not isolated from urine because they were either not present when the specimens were taken or were inhibited in some way.

TABLE II

Isolation of virus from a child with fatal varicella indicated by the production of a CPE in human amnion and human thyroid cultures

\begin{tabular}{|c|c|c|c|}
\hline \multirow{2}{*}{\multicolumn{2}{|c|}{ Specimen cultured }} & \multicolumn{2}{|c|}{$\begin{array}{l}\text { Production of CPE (and day of culture } \\
\text { CPE first seen) in }\end{array}$} \\
\hline & & amnion culture & thyroid culture \\
\hline $\begin{array}{l}\text { Skin swab } \\
\text { Vesicle fluid } \\
\text { Heart fluid* } \\
\text { Lung }\end{array}$ & $: \quad:$ & $\begin{array}{l}- \\
+ \\
-\end{array}$ & $\begin{array}{l}+(4) \\
+(3) \\
+(7) \\
+(6)\end{array}$ \\
\hline
\end{tabular}

* Fluid aspirated from the heart region was either serum or pericardial fluid.

Isolation of virus from fatal varicella in a child. A number of specimens from a fatal case of varicella in a 13-yr-old girl were cultured. Swabs were taken from skin lesions $24 \mathrm{hr}$ before death, and vesicle fluid, fluid aspirated from the heart region and a sample of lung were collected at necropsy $48 \mathrm{hr}$ after death. All these specimens yielded infectious virus when tested in human thyroid cells, but only vesicle fluid did so when tested in human amnion cells. Despite the time lag after death before collection of the specimens the interval before appearance of cytopathic changes was short (table II).

TABLE III

Isolation of virus from an adult with fatal zoster indicated by the production of a CPE in a human amnion culture

\begin{tabular}{lll|c}
\hline \multicolumn{1}{l}{ Specimen cultured } & & Production of CPE (and day of culture \\
CPE first seen)
\end{tabular}

Isolation of virus from fatal zoster in an adult. Specimens of liver and lung, and of skin that had several vesicular lesions, were obtained at necropsy from a 52-yr-old woman who died during an attack of thoracic zoster. Virus was isolated in human amnion cultures from skin and lung, but not from the liver (table III). On this occasion human thyroid cultures were not available.

Isolation of virus from the ganglia of the fifth cranial nerve. No viruses were isolated from the 66 cranial nerve ganglia investigated. 


\section{Growth of viruses in cell cultures}

Human amnion, human thyroid, human embryo lung, HeLa, rhesus monkey kidney, vervet monkey kidney and V3A cultures all supported the growth of the Marsden and Pittaway strains of virus. In each culture characteristic cytopathic changes were observed from the 3 rd to the 21 st day. The cytopathic change was focal, developed slowly and resembled the changes described by Weller and by Taylor-Robinson. However, it was noted that there was often

\section{TABLE IV}

Survival of infectious varicella and zoster viruses on storage of infected human amnion cell cultures at $-65^{\circ} \mathrm{C}$ indicated by the production of a CPE on subsequent passage in human amnion and human thyroid cultures

\begin{tabular}{|c|c|c|c|c|c|}
\hline \multirow{2}{*}{$\begin{array}{l}\text { Stored } \\
\text { bottle } \\
\text { no. }\end{array}$} & \multirow{2}{*}{ Strain of virus } & \multirow{2}{*}{$\begin{array}{l}\text { No. of } \\
\text { culture } \\
\text { passage }\end{array}$} & \multirow{2}{*}{$\begin{array}{l}\text { Period of } \\
\text { storage } \\
\text { (mth) }\end{array}$} & \multicolumn{2}{|c|}{$\begin{array}{l}\text { Production of CPE (and day of } \\
\text { culture CPE first seen) on subsequent } \\
\text { passage in two* }\end{array}$} \\
\hline & & & & amnion cultures & thyroid cultures \\
\hline $\begin{array}{l}1 \\
2 \\
3 \\
4 \\
5\end{array}$ & $\begin{array}{l}\text { Pittaway } \\
\text { Pittaway } \\
\text { Pittaway } \\
\text { Pittaway } \\
\text { Zoster R }\end{array}$ & $\begin{array}{c}13 \\
4 \\
5 \\
5 \dagger \\
7\end{array}$ & $\begin{array}{l}35 \\
31 \\
30 \\
30 \\
19\end{array}$ & $\begin{array}{l}+(8),- \\
+(8),- \\
+(18),- \\
+(20),-\end{array}$ & $\begin{array}{l}+(8),+(8) \\
+(8),+(8) \\
+(8),+(8) \\
+(8),+(8) \\
+(8),+(8)\end{array}$ \\
\hline $\begin{array}{r}6 \\
7 \\
8 \\
9 \\
10 \\
11\end{array}$ & $\begin{array}{l}\text { Marsden } \\
\text { Varicella } 129 \\
\text { Varicella } 1697 \\
\text { Varicella } 121 \\
\text { Varicella } 730 \\
\text { Varicella } 8\end{array}$ & $\begin{array}{r}13 \\
3 \\
6 \\
4 \\
8 \\
5\end{array}$ & $\begin{array}{l}20 \\
20 \\
35 \\
20 \\
20 \\
20\end{array}$ & $\begin{array}{l}\overline{+}(18),- \\
\overline{-}(8),- \\
+(8),+(8) \\
+(18),-\end{array}$ & $\begin{array}{l}+(8),+(8) \\
+(8),+(8) \\
+(10),+(18) \\
+(8),+(8) \\
+(8),+(8) \\
+(8),+(8)\end{array}$ \\
\hline
\end{tabular}

* Results are shown for two cultures of each type of cell. The four cultures had received parallel inocula of the stored and thawed infected culture.

$\dagger$ Bottle previously thawed once and re-frozen.

an extensive network of cytoplasmic strands between the cells both in human thyroid and in primary vervet kidney cultures (figs. 1 and 2). The appearances produced by the Marsden and Pittaway strains of virus were similar. No effect was observed in RK13 cultures.

Neither the Marsen nor the Pittaway viruses were recovered in supernatant tissue-culture fluids, nor were they found after ultrasonic treatment of infected cells. After rapid freezing and thawing, minimal amounts of both strains (1--3 foci of CPE) were noted in human thyroid, human amnion or human embryo lung cells into which the extracellular fluids had been inoculated.

\section{Storage of the viruses}

All the strains of virus were recovered from flat-bottle cultures of infected human amnion cells that had been placed directly at $-65^{\circ} \mathrm{C}$ (table IV). The 
longest period of storage was $35 \mathrm{mth}$. In four instances (bottles no. $4,6,8$, 10 in table IV) virus was detected in human thyroid but not in human amnion cultures. Cytopathic changes always appeared in the human amnion cells later than in thyroid cells.

The virus present in human amnion and human thyroid cells suspended in either 10 per cent. dimethylsulphoxide or 10 per cent. glycerol was recovered after storage for $3 \mathrm{mth}$ at $-65^{\circ} \mathrm{C}$ (table $\mathrm{V}$ ), and no difference was noted in the protection given by either substance. After $29 \mathrm{mth}$ only the Marsden strain preserved in dimethylsulphoxide was still viable. Storage of virus strains in

\section{TABLe V}

Survival of infectious varicella (Marsden) and zoster (Pittaway) viruses in human amnion and human thyroid cell cultures containing 10 per cent. dimethyl sulphoxide (DMSO) or 10 per cent. glycerol during storage at $-65^{\circ} \mathrm{C}$

\begin{tabular}{c|c|c|c|c}
\hline \multirow{2}{*}{$\begin{array}{c}\text { Period of storage } \\
\text { at }-65^{\circ} \mathrm{C}\end{array}$} & \multicolumn{2}{|c|}{$\begin{array}{c}\text { Survival* of Marsden strain in } \\
\text { cultures containing }\end{array}$} & \multicolumn{2}{c}{$\begin{array}{c}\text { Survival* of Pittaway strain in } \\
\text { cultures containing }\end{array}$} \\
\cline { 2 - 5 } & DMSO & glycerol & DMSO & glycerol \\
\hline & + & + & $\ldots$ & $\ldots$ \\
37 days & $\ldots$ & + & + & $\ldots$ \\
3 days & + & $\ldots$ & $\ldots$ & + \\
\hline
\end{tabular}

* With the exception of the 29-mth sample, survival was demonstrated by the production of a cytopathic effect in human amnion cultures into which the stored material was inoculated. Survival of the 29-mth sample was demonstrated by the production of cytopathic effect in human thyroid cultures.

$\ldots=$ Not tested.

liquid nitrogen at $-184^{\circ} \mathrm{C}$ was also effective in preserving the infectivity of the virus. The lung suspension containing Pittaway virus was found to be still infectious after storage at $-65^{\circ} \mathrm{C}$ for 4 yr $8 \mathrm{mth}$.

\section{DiSCUSSION}

Varicella-zoster viruses were isolated in human amnion and human thyroid cultures from clear vesicle fluids obtained from early skin lesions in patients. The thyroid cultures were the more sensitive, as shown by an earlier appearance of cytopathic changes. Virus was isolated both from the vesicle fluid and from the lung from the fatal case of chickenpox and from the fatal case of zoster studied. Identification of the viruses rested mainly on the appearance of characteristic cytopathic changes, but was confirmed by a complement-fixation test with the unknown material as antigen. Such antigens were produced from the Marsden and no. 1697 strains of varicella virus and the Pittaway and R strains of zoster virus grown in human amnion cultures.

A random but unsuccessful search was made for these viruses in the ganglia of the fifth cranial nerve of 66 elderly patients who had died from diseases other 
than chickenpox and zoster. Earlier, Hope-Simpson (1965) had suggested that the virus of chickenpox persists in the sensory ganglia and that zoster is due to reactivation of this virus. Hope-Simpson also found ophthalmic zoster to be frequent. It is possible that an alternative approach by the application of a fluorescent antibody technique might be more successful.

Virus was not found in the urine of 23 patients with chickenpox and in one patient with zoster, and in this respect varicella and zoster viruses differ from cytomegalovirus.

Both the Marsden and Pittaway viruses grew in all cultures studied except the RK13 cells. Virtually no cell-free virus was obtained from these cultures. The amount of virus in fluids obtained after repeated cycles of freezing and thawing was minute and unsuitable for further experiments. The absence of infectious virus in culture fluids is surprising, because mature virus particles exist in an apparently free state at the surface of the cultured cells as shown in electron-micrographs of the Marsden virus in amnion cultures (Achong and Meurisse, 1968). It is possible that cell-free virus in culture fluids is subject to some inhibitory factor. Although trypsin does not completely inactivate the varicella-zoster viruses when added to cell cultures for the serial passage of the viruses, it has been shown (Brunnell, 1967) to have an adverse effect upon the infectivity of the viruses. This deleterious action, and the effect of the ultrasonic treatment on the cell suspensions infected with varicella or zoster, may account for the lack of success in obtaining these viruses in a cell-free state.

The survival of viable virus was demonstrated when infected human amnion cells were stored at $-65^{\circ} \mathrm{C}$. The longest period of survival demonstrated was almost 3 yr. When a bottle containing infectious Pittaway virus was thawed, a portion of the infected cells was removed, and the remaining cells were frozen and stored for a further period, viable virus was again obtained. It appeared that cell-associated particles were able to withstand at least one cycle of freezing and thawing. Viruses were satisfactorily stored at $-65^{\circ} \mathrm{C}$ or $-184^{\circ} \mathrm{C}$ in cell suspensions containing either 10 per cent. dimethylsulphoxide or 10 per cent. glycerol, although inactivation of some infectious virus took place. In recovering stored viruses the increased sensitivity of thyroid over amnion cultures was evident.

In HeLa cell cultures infected with varicella or zoster virus, the cytopathic effect was not always easy to detect, especially after fresh maintenance medium had been added. Of the continuous cell lines, human embryo lung and V3A cells are therefore more likely to be suitable for use in a routine test. The irregular supply of human thyroid tissue makes its use in neutralisation tests impracticable.

Within the herpes group, varicella-zoster virus, the EB virus from Burkitt's lymphoma (Epstein, Achong and Barr, 1964) and cytomegalovirus are found to be mainly if not completely cell-associated. This close cell association in the behaviour of varicella and zoster viruses accounts for the present lack of a standard serum neutralisation test. The solution of the problem of when immunity to chickenpox wanes and susceptibility to zoster starts therefore awaits further developments. 


\section{VARICELLA-ZOSTER VIRUS}

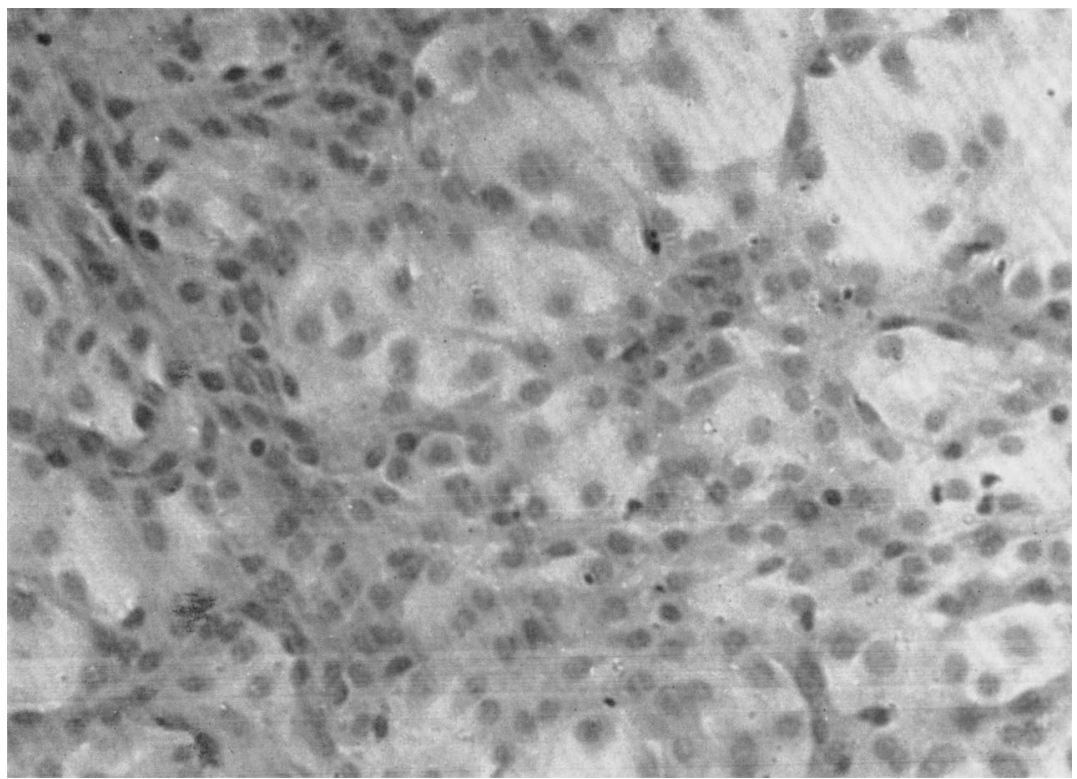

FIG. 1.-Human thyroid culture without virus. Haematoxylin and eosin. $\times 120$.

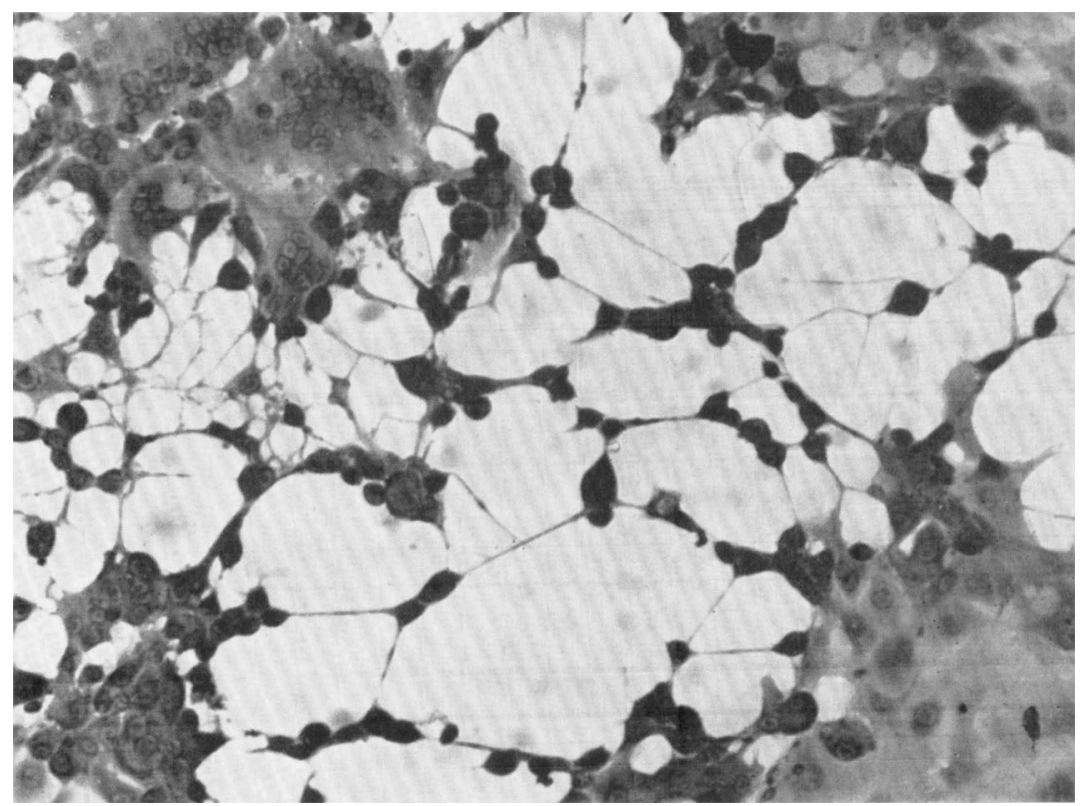

FIG. 2.- Human thyroid culture 7 days after inoculation of Pittaway virus (5th passage) showing characteristic groups of small rounded cells held together by a network of cytoplasmic strands. Multinucleate giant cells are also present. HE. $\times 120$. 


\section{SUMMARY}

In a study of varicella-zoster virus, one strain isolated from a patient with varicella and one strain from a patient with zoster were grown in a range of different cell cultures. The viruses grew in human amnion, human thyroid, human embryo lung, HeLa, rhesus monkey kidney, vervet monkey kidney and V3A cultures. They behaved identically, giving similar cytopathic changes in the same range of cell cultures. Neither virus could be readily obtained in a cell-free state. The isolation of varicella-zoster viruses in cell cultures was accomplished from vesicle fluids of 15 patients with chickenpox and one patient with zoster, and from lung tissue of a fatal case of chickenpox and a fatal case of zoster. Virus was not isolated from the urine of 23 patients with chickenpox and one patient with zoster, nor from the ganglia of the fifth cranial nerve of 66 elderly persons who had died from causes other than chickenpox and zoster. Both viruses in cell cultures were stored satisfactorily for several years at either $-65^{\circ}$ or $-184^{\circ} \mathrm{C}$ and human thyroid cultures were the most suitable cultures for their subsequent recovery.

I wish to thank Dr J. Vahrman and Mr S. H. W. Cooper, Western Hospital, London, for the facilities and assistance received in the collection of specimens, and $\mathrm{Mr} \mathrm{W}$. Clifford for the photographs.

\section{REFERENCES}

Achong, B. G., AND Meurisse, E. 1968. J. Gen. Virol., 3, 305.

VALERIE

BrunNell, P. A.

Caunt, Anne E.

Epstein, M. A., Achong, B. G., AND BARR, Y. M.

GOLD, E.

HAYFliCK, L., AND MOORHEAD, P. S.

HOPE-SIMPSON, R. E.

Lane, W. F., and Marshall, J.

Nagington, J., ANd Greaves, R. I. N. .

Pereira, H. G., and Kelly, Barbara .

Pulvertaft, R. J. V., Davies, Joan R., Weiss, L., ANd Wilkinson, J. H.

RAPPAPORT, CATHERINE

Stern, H., Lambert, H. P., and ShakeSPEARE, W. G.

TAYLOR-ROBINSON, D. .

VÁCZy, L., Géder, L., Koller, M., AND BODA, D.

WELLER, T. $\mathrm{H}$.

Weller, T. H., AND StODdARD, MARGUERITE B.

Weller, T. H., Witton, Helen M., AND BELL, E. J.
1967. Virology, 31, 732.

1963. Lancet, $2,982$.

1964. Lancet, 1, 702.

1965. J. Immun., 95, 683.

1961. Expl Cell Res., 25, 585.

1965. Proc. Roy. Soc. Med., 58, 9.

1957. Mon. Bull. Minist. Hlth, 16, 198.

1962. Nature, Lond., 194, 993.

1957. J. Gen. Microbiol., 17, 517.

1959. J. Path. Bact., 77, 19.

1956. Bull. Wld Hlth Org., 14, 147.

1963. Archs Dis. Childh., 38, 626.

1959. Br. J. Exp. Path., 40, 521.

1962. J. Hyg. Epidem. Microbiol. Immun., 6, 462.

1953. Proc. Soc. Exp. Biol. Med., 83, 340.

1952. J. Immun., 68, 311.

1958. J. Exp. Med., 108, 843. 